\title{
Geoscience for the public: Geotopes and National GeoParks in Germany
}

\author{
1 Lower Saxony Geological Survey, Stilleweg 2, D-30657 Hannover, Germany; E-mail: gerd.roehling@bgr.de \\ 2 Federal Institute for Geoscience and Natural Resources, Stilleweg 2, D-30657 Hannover, Germany; E-mail: m.schmidt-thome@bgr.de
}

\begin{abstract}
Geotopes or geological sites provide information on the evolution, structure and properties of the Earth's crust and on the geological past. They also represent the great variety of features that characterize a landscape. For this reason, their preservation is of special concern to geosciences.

As early as in the 19th century outstanding rock formations became important tourist sites although the modern terms "geosites" and "geotourism" were unknown. The paper describes the German initiatives on geotope conservation and the implementation of National GeoParks in Germany and their use for education and tourism.
\end{abstract}

\section{Introduction}

The increasingly intensive exploitation of our planet and its resources, and the growing need to maintain and protect the environment in which we live, mean that geosciences are becoming increasingly important for solving the problems associated with development . It is important for geoscientists to improve public awareness about the ability of geoscience to provide reliable predictions and concepts for our planet.

Geological sites - in Germany called geotopes - provide information on the evolution, structure and properties of the Earth's crust. They also contain the great variety of features that characterize a landscape and are commonly the site of habitat of endangered animals and plants. For this reason, their preservation is of special concern to geosciences and for the protection of threatened animal and plant species. One of the responsibilities of a Geological Survey is to provide the scientific basis for selection and legal protection of sites for conservation. Geosciences in Germany have both the opportunity and necessity to inform the public and provide a forum for discuss ion of geoscientific topics.

In the past, geological sites and large areas of special geological significance have been designated as natural monuments (Figure 1) and

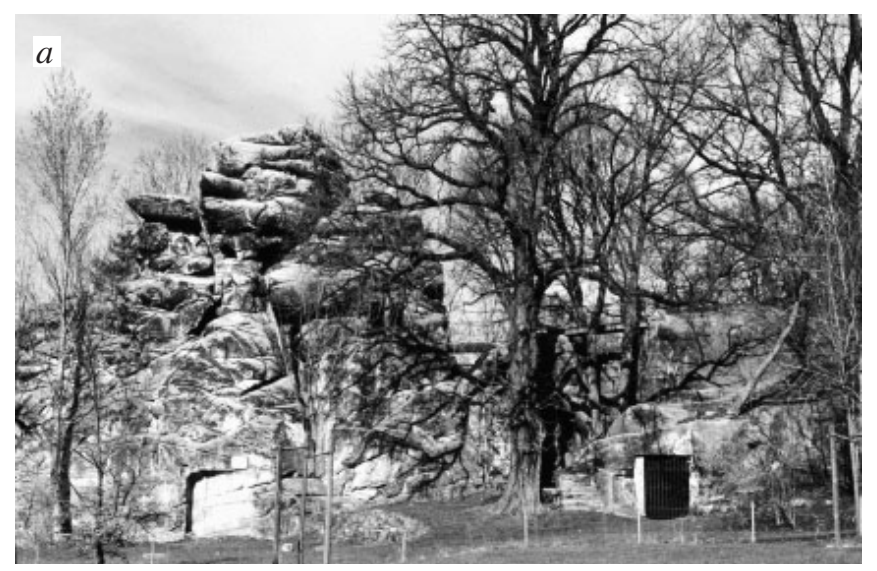

archaeological sites of special value, and placed under legal protection by appropriate governmental agencies. However, these measures have not been based on the evaluation of systematic and comprehensive geoscientific inventories. They have been primarily motivated by interest in biological aspects of the environment and are the result of the work of nature conservation agencies fostering local history, geography and traditions. Groups and individuals interested and engaged in conservation matters have also been active in promoting sites.

\section{Legal base}

The legal provisions for geotope conservation are not uniform across Germany. The Nature Conservation Law and the Natural Monument Law (covering archaeological sites and fossil localities) are considered the main legal provisions for implementation of geotope conservation. At present, there are no definitive standards for geotope conservation in the federal or state legislation in Germany.

The responsibility for all matters dealing with nature conservation lies with the 16 federal states. Each individual state creates its own legislation within the limits of the Federal Law on Nature Conservation. These laws contain some provisions compatible with the requirements of geotope conservation. They provide for the legal protection of geological exposures as natural monuments which also may be fossiliferous as well as other geological features such as landforms and springs. In addition, in some federal states, fossils and fossil localities are included under natural monuments in the legislation (Baden-Württemberg, Brandenburg, Hesse, North Rhine-Westphalia, Rhineland-Palatine, Thuringia). Very few of the federal states have regulations on the implementation of geotope conservation, i.e., protection and maintenance measures are not specified, nor is any provision made for regulating access to sites for scientific research work.

A further possibility of meeting the requirements of geotope protection is within the framework of regional land-use planning. In many of the federal states, various procedures are obligatory, including official announcements, administrative regulations, decrees, etc., with due regard to geotope conservation.

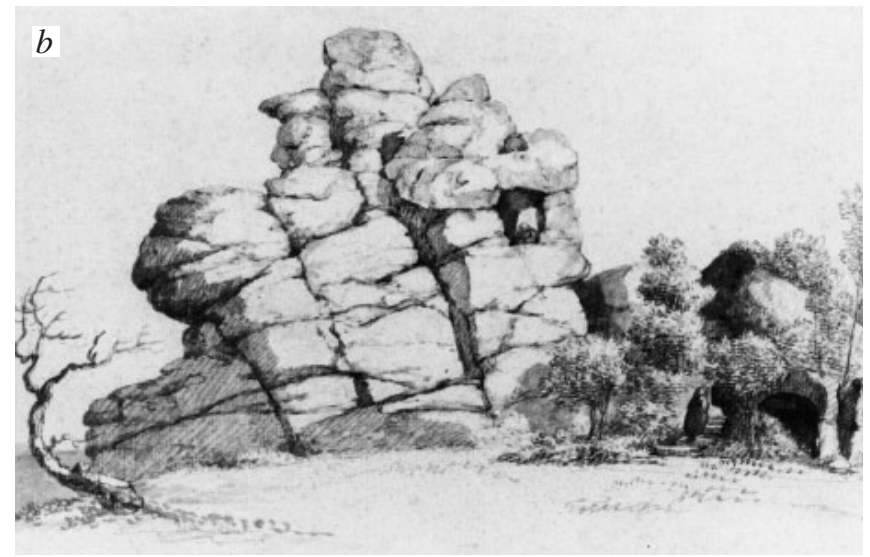

Figure 1 The Klusfelsen (Rock of Klus) near the city of Goslar (Lower Saxony) is a geotope visited by J.W. von Goethe in the 18th century. The original chalk (1a) and ink drawings (1b) are preserved in the Goethe-Nationalmuseum in Weimar. 


\section{Organisations and policy}

Inventory and assessment of geotopes requires well-founded scientific information and knowledge. With rare exceptions, the agencies responsible for the protection and maintenance of geotopes do not have the necessary knowledge or experience. These responsibilities require sound geoscientific knowledge, close cooperation between various geoscientific disciplines, and a comprehensive knowledge of regional geology. Inventory and assessment of geotopes for conservation should be the responsibility of the State Geological Surveys.

Due to the wide spectrum of possible reasons for nature conservation, geotope conservation is often faced with competing interests In order to keep the number of conflict cases to a minimum, only those sites where scientific or public interest exists should be placed under legal protection. Geotope conservation must be handled flexibly so that all interests in the preservation of such sites can be taken into consideration from the very beginning. Alternative sites may need to be included into consideration, and solutions must be favored that guarantee mutual interest. The Geological Surveys of the federal states are responsible for working out the geoscientific side of this balance of interest. A report of their investigations is submitted to the agencies responsible for placing sites under legal protection, in general, to the nature conservation agencies.

\section{Site selection}

Due to the different regional competencies and procedures within and between the German federal states, reliable and comparable data on the total number and significance of geotopes are not available. To obtain representative data, the geology of the areas being compared with each other must be investigated in detail and in the same way. This has been the case, however, in only a few of the federal states. Procedures that are agreed upon by all of the German federal states and comparable standards are needed for systematic geotope conservation. Therefore, in 1992, Directors of the State Geological Surveys and the Federal Institute for Geosciences and Natural Resources (BGR) decided that the Geological Surveys should set up a working group to work out a concept for geotope conservation.

First of all, the objects of inventory, e.g. the terms "geotope" and "geotope of nature conservation value" need to be clearly defined. Therefore in 1994 the group was commissioned as the Ad-hoc Geotope Conservation Working Group. The results of their work have been presented in the "Guidelines for Geotope Conservation in Germany".

Geotopes are defined as geological features of inanimate nature which provide information on the development of the Earth or of past Life. They include exposures of rocks, especially those showing fossil soils, minerals of special interest, and fossil plants and animals, as well as individual natural phenomena and outstanding natural features of the landscape.

Geotopes of nature conservation value are defined as those geotopes of special geological significance, rarity, uniqueness or beauty. They are of special value for science, research and teaching, or to local history and geography. They may require legal protection, especially if they are threatened, and comparable geotopes are not available.

Geotope conservation is defined as that part of nature conservation that deals with the preservation of geotopes of nature conservation value. The actual inventory and assessment of geotopes, as well as the decisions about protection and maintenance measures needed for geotopes of nature conservation value, are the responsibilities of the Geological Surveys of the individual federal states. The regulations are implemented by the relevant nature conservation agencies.

Geotopes are part of our natural geological heritage. They may be threatened by construction, weathering, vegetation growth, or other processes or events. In general, they are irreplaceable; in a few cases, they are replaceable but only at great expense. Therefore, besides the scientific interest, there is also a considerable public interest in the preservation of significant geotopes.
However, in contrast to biotope conservation, for which certain defined biotope types are protected in Germany without being inventoried, it is not possible to place all geotopes of a certain type automatically under protection. The only geotopes that should be placed under legal protection are those of special geological significance and rarity, uniqueness or beauty, or value to science, research and teaching, or to local history and geography.

This means that only geotopes of special significance should be placed under legal protection, especially when their continued existence or characteristic features are threatened, and comparable sites do not exist.

Therefore, geotope conservation should also be specified in the Federal Nature Conservation Law and in the nature conservation laws of the individual states.

Normally, geotopes of nature conservation value should be designated as natural monuments, as protected natural features or, in the case of large areas, as nature reserves.

\section{Registration}

Protection of geological sites, as well as large areas of special geological interest, can be initiated by governmental agencies or individuals. Nature conservation agencies are normally responsible for placing sites under legal protection. Before the process of legal protection is started, the submitted proposals need to be revised by the respective State Geological Survey.

\section{Protected sites/Protection}

A comprehensive geotope conservation law must provide for the continued existence of geotopes that are significant for, characteristic of or unique in a physiographic region, regional geological unit or geological period. However, this objective can only be achieved if all the geological features of the area in question have been inventoried in a consistent manner (see Table 1).

It is advisable to inventory geotopes in steps. The first step should provide an overview of the geotopes in a certain physiographic region. In the second step, more information is compiled about the individual geotopes. Finally, a complete inventory of the entire physiographic region is made. This inventory is used for the subsequent comparative assessment of all sites.

Table 1 Inventories of geotopes in Germany (status: 1994).

\begin{tabular}{|c|c|c|c|}
\hline Federal states & $\begin{array}{l}\text { Number of } \\
\text { geotopes } \\
\text { inventoried }\end{array}$ & $\begin{array}{c}\text { Area of the } \\
\text { federal state } \\
\left(\mathbf{k m}^{2}\right)\end{array}$ & Documentation status \\
\hline Berlin & 45 & 883 & general survey \\
\hline Baden-Württemberg & 3195 & 35.751 & general survey \\
\hline Bavaria & 2910 & 70.547 & general survey \\
\hline Brandenburg & 500 & 29.475 & $\begin{array}{l}\text { general survey and detailed survey } \\
\text { in part of the state }\end{array}$ \\
\hline Hamburg & 33 & 755 & complete inventory \\
\hline Hesse & 435 & 21.113 & general survey \\
\hline Mecklenburg-Vorpommern & $\mathrm{rn} \quad 430$ & 23.167 & $\begin{array}{l}\text { general survey and detailed survey } \\
\text { in part of the state }\end{array}$ \\
\hline Lower Saxony + Bremen & 1500 & 47.768 & complete inventory \\
\hline North Rhine-Westphalia & 3200 & 34.068 & $\begin{array}{l}\text { general survey and detailed survey } \\
\text { in part of the state }\end{array}$ \\
\hline Rhineland-Palatinate & 40 & 19.852 & general survey in part of the state \\
\hline Schleswig-Holstein & 365 & 15.732 & general survey \\
\hline Saarland & 384 & 2.570 & general survey in part of the state \\
\hline Saxony & 650 & 18.407 & $\begin{array}{l}\text { general survey and detailed survey } \\
\text { in part of the state }\end{array}$ \\
\hline Saxony-Anhalt & 520 & 20.444 & general survey \\
\hline Thuringia & 449 & 16.175 & general survey \\
\hline
\end{tabular}


The geotopes then are assessed to determine whether they merit legal protection and to establish what criteria are necessary to achieve the goals of geotope conservation. They must include further procedures for placing geotopes under legal protection.

A geotope is assessed in two steps. First, its geoscientific value is assessed on the basis of geological criteria and rarity. Its need for legal protection is determined on the basis of how seriously the geotope is threatened and what the legal protection status of comparable geotopes is. On the basis of these two steps, the geotope is assigned to a conservation category. Recommendations are then made as to whether it is necessary to place the site under legal protection in accordance with the Nature Conservation Law, or to include it in land-use planning documents.

\section{Management and facilities: Education and tourism}

\section{The Year of Geoscience, 2002}

In 1999, the German Federal Ministry of Education and Research launched the Science Dialog campaign. As part of this campaign, special fields of science are highlighted each year to encourage the discussion between scientists and interested persons of all ages (Figure 2). The year 2002 was proclaimed the "Year of Geoscience".

Geosciences have made remarkable advances in the past decades. Geoscientists have increased the understanding of the "Earth system"- the geosphere, hydrosphere, biosphere and atmosphere. We now have a much better understanding of the interactions that occur in this finely tuned "System".

Increasing communication is needed to make these exciting findings available to the public, and to put people into a position to discuss topics at meetings, at functions or through the media.

As part of the efforts to promote understanding of the complex topics covered by geoscientific research, a platform for intensive communication has been offered. The German Federal Ministry of Education and Research together with the Science Dialog campaign has held four major events under the banner of "Planet Earth" during the Year of Geoscience (Figure 3) to stimulate interesting discussions and to present well-founded information. These activities dealt with the entire spectrum of modern geoscientific research, broken down into four categories: Earth, Air, Fire and Water.

Approximately 750,000 visitors participated in more than 2,500 events. Nearly 245,000 people attended the 4 central events, and more than 230,000 visitors took part in 13 other events, among which was the Day of the Geotope.

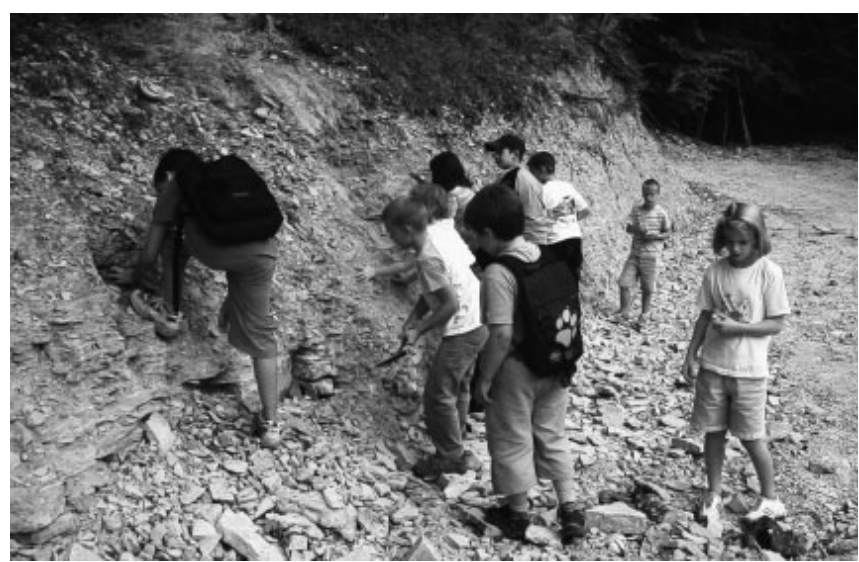

Figure 2 Adventure in Quarry Hainhol, National GeoPark HarzBraunschweiger Land - Ostfalen, Lower Saxony.

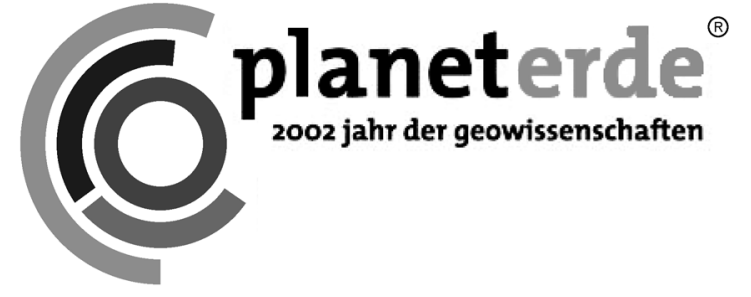

Figure 3 Logo Planet Erde.

\section{Day of the Geotope}

The Day of the Geotope was organized on 6 October 2002. The main target group was the public which normally have little to do with geosciences. The Day of the Geotope offered the public 350 significant geological objects of all kinds all over Germany, e.g. outcrops with tectonic or stratigraphic features, fossil sites (not only those with dinosaur footprints), abandoned and active underground and open pit mines (Figure 4), etc. Altogether about 25,000 visitors took the opportunity to be introduced to the various 'secrets' of the geosciences.

Due to the positive resonance of the public (Figure 5), it was decided to have the Day of the Geotope every year in September.

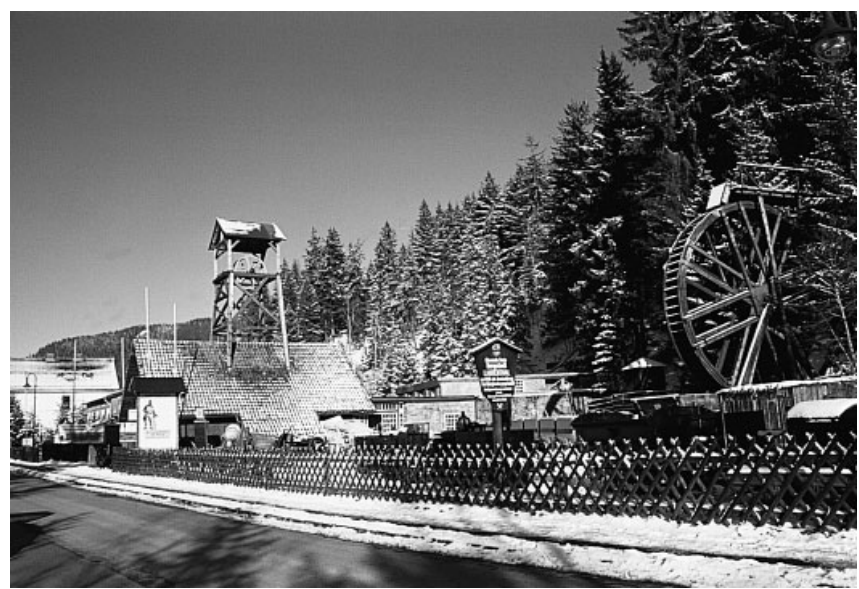

Figure 4 Underground mining museum "Lautenthals Glück", National GeoPark Harz - Braunschweiger Land - Ostfalen, Lower Saxony.

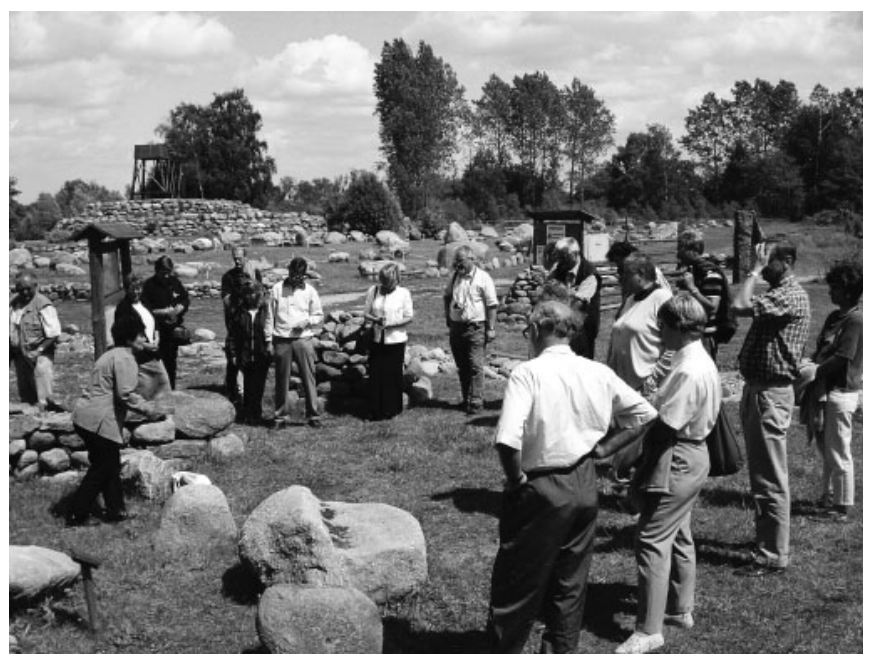

Figure 5 Garden of erratic blocks in Schwichtenberg, National GeoPark Mecklenburgische Eiszeitlandschaft (Ice age landscape), Mecklenburg-Vorpommern. 


\section{National GeoParks}

A comparatively high level of activities in the field of site management and exploitation of geotopes for educational and touristic purposes can be observed in the National GeoParks in Germany, which were established as a follow-up to the German "Year of Geoscience".

In national geoparks, the public can be made aware of-and experience first hand-the significance of geological and geomorphological processes to the distribution of natural resources, to land use, to the topography, and to the economic and cultural history. In these parks, the aims of environmental protection can be related to the need for socially compatible, regional economic development. By presenting and maintaining the geological heritage together with its sustainable utilization, national geoparks should contribute to the realization of the objectives of the Agenda 21 (UNCED, Rio de Janeiro, 1992) and the World Summit for Sustainable Development (WSSD, Johannesburg 2002). Aspects of economic development with emphasis on tourism and recreation should be included in the planning. This concept requires cooperation between various scientific fields.

The UNESCO Executive Council has approved the support for national geopark initiatives. National geoparks can be part of a UNESCO network, with the objective of improving the understanding and sustainable use of the Earth's natural resources. With this aim in mind, a national geopark within a UNESCO network should be open to tourism.

The UNESCO concept has three objectives. In addition to maintaining an intact environment, stimuli should be provided for sustainable economic development and an improved general understanding of geoscientific viewpoints. Also, a geopark should aid recognition and maintenance of our geoheritage and sensitize the public to a balanced relationship between humans and the planet Earth. In a holistic approach, geoscientific, cultural and socio-economic aspects should unite to promote sustainable development.

According to the UNESCO definition of geopark, a national geopark contains geological features of interest (geotopes) of any size or a group of geotopes that are of regional and national geoscientific interest, rarity or beauty, and representative of a landscape and its geological history. In addition to geological aspects, there should be archeological, ecological, historical or cultural features that can be developed for tourism. A national geopark has clearly defined boundaries and has a large enough area to ensure that it can contribute to the economic development of the community. The administration of the geopark must have a clearly defined structure.

The individual features of a national geopark are to be open to the public and related to each other. The geopark operator must present a realistic scientific and tourism concept. It must demonstrate that it is able to appropriately maintain the features of the geopark.

The aim of a national geopark should be to promote the sustainable economic development of the region, educate the public about the environment, and contribute to the teaching and research in the geosciences. All activities should be accompanied by appropriate public relations activities.

A national geopark contributes to the preservation of important geological features that provide information for the different geoscientific disciplines, e.g. pedology, geography, geomorphology, geophysics, glacial geology, speleology, hydrogeology, engineering geology, mineralogy, paleontology, petrography, economic geology, mining, sedimentology, stratigraphy, structural geology and volcanology. The operator of a geopark is expected to maintain the individual geotopes in agreement with the Survey. It is recommended that operators contact the State Geological Survey of the respective state as early as possible, as the State Geological Surveys can provide advice to geopark projects as well as the respective state administration.

An application for designation as a National GeoPark with the right to use the planeterde ${ }^{\circledR} \log$ o should be submitted to the AlfredWegener-Stiftung zur Förderung der Geowissenschaften (AWS). There is no fee for submission of the application.

Applicants for designation as a National GeoPark are requested to submit the following information:
- Brief description of the GeoPark

- Scientific significance of the GeoPark

- Plan for sustainable development of the GeoPark region

It must be shown in the application that the geopark is in the public interest and does not violate any laws. The application must include explanations (e.g., from government agencies and institutions) to this effect.

The scientific quality of the geopark is to be assessed by the respective State Geological Survey before the application is submitted.

AWS will appoint a National GeoPark Group of Experts to assess the applications for a geopark, so that the assessment will be uniform throughout Germany. Non-geological aspects will also be evaluated. The Group of Experts will consist of a core group of 11 permanent members. Besides the core group a list of experts will be drawn up for consultation in the different disciplines as required.

Depending on the assessment of the National GeoPark Group of Experts, AWS can approve or decline the use of the planeterde ${ }^{\circledR} \operatorname{logo}$.

After certification a National GeoPark will be allowed to use the planeterde ${ }^{\circledR} \log$ o for a five year periods, approved by the AWS in agreement with the Federal Ministry of Education and Research. Thus, a symbol introduced for the activities of the Year of the Geoscience 2002 will be given a further meaningful application.

The condition of each National GeoPark will be evaluated by AWS every five years on the basis of a report submitted by the operator of the geopark.

If the assessment establishes that the National GeoPark no longer fulfills the criteria, AWS will recommend the appropriate steps to be taken by the operator. If the operator of the National GeoPark does not fulfill these recommendations for maintaining the requirements within an appropriate time, the designation as National GeoPark and the planeterde ${ }^{\circledR} \log 0$ will be withdrawn by AWS.

In May 2003, the AWS officially awarded four applicants (Figure 6) with the National GeoPark certificate, and allowed the use of

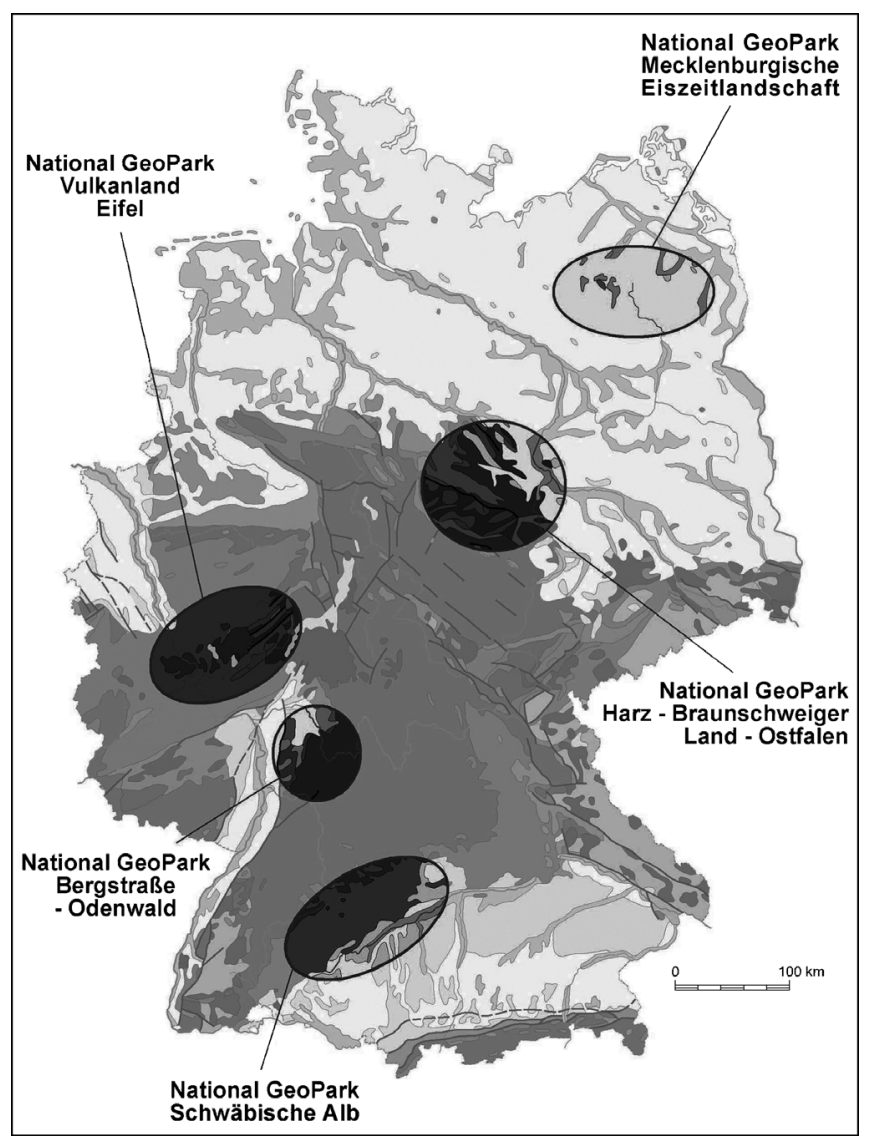

Figure 6 National GeoParks in Germany. 
the planeterde ${ }^{\circledR} \log 0-$ "World of the Geosciences". The logo is now the certificate of quality for the German National GeoParks within the scope of the UNESCO "National Parks" network.

\section{Important Geotopes in Germany}

After the inventory and assessment of geotopes, the next step is to select those geotopes which are of national (and international) importance (Quade 2003). In autumn 2003, a public call was initiated to receive from the population proposals for the most beautiful and most interesting geotopes in Germany. Selection and assessment of the proposals submitted is to be effected according to uniform cri-

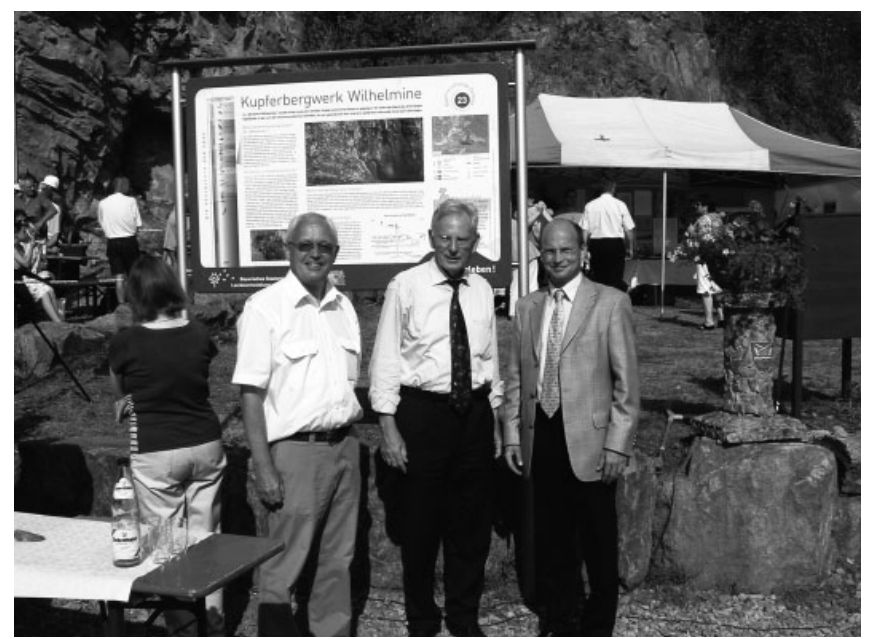

Figure 7 Opening ceremony for the 27th Bavarian geotope, the former Copper Mine Wilhelmine, on the occasion of the project "100 Geotopes in Bavaria".

teria by a national expert group that was also formed in 2003 . Accepted proposals will be made available via internet for public discussion. The applicant has one year to present detailed reasons, including a scientific elaboration of the project.

There are also initiatives on federal states' level to define geotopes of special interest for the individual state, e.g. the "100-Geotope-Project" in Bavaria (Figure 7) (Brandt et al., 2003).

\section{References}

Ad-hoc-AG Geotopschutz, 1996, Geotopschutz in Deutschland - Leitfaden der Geologischen Dienste der Länder der Bundesrepublik Deutschland. Geotope Conservation in Germany-Guidelines of the Geological Surveys of the German Federal States. Angewandte Landschaftsökologie, Heft 9, 105 S.; Bonn-Bad Godesberg.

Brandt, S., Eichhorn, R., Glaser, S., Birkenhauer, J., Lagally, U., \& Lehrberger, G., 2002, Das 100-Geotope-Projekt-ein Beitrag zum sanften Geo-Tourismus. In: Kruhl, J. H., Birkenhauer, J., Lagally, \& Lehrberger, G. (Hrsg.): Geowissenschaften und.Öffentlichkeit 6. Internationale Tagung der Fachsektion GeoTop in der Deutschen Geologischen Gesellschaft, 10.-13.04.2002 in Viechtach. Schriftenreihe der Deutschen Geologischen Gesellschaft, Heft 25: 66-70; Hannover.

Bundesministerium für Bildung und Forschung-BMBF, 2002, System Earth. 2002 - The year of geoscience, 27 p.; Berlin.

Look, E.-R. \& Junker, B., 2003, "Tag des Geotops"- Präsentation geologischen Sehenswürdigkeiten. In: Quade, H. (Hrsg.): Geoforum 2003. Geotope-Geoparks-Geotourismus. Schriftenreihe der Deutschen Geologischen Gesellschaft, Heft 25: 24-30; Hannover.

Mattig, U. (für die Koordinierungsgruppe "Geoparks" des Bund-Länderausschuss Bodenforschung: Dieter Göllnitz, Kurt Goth, Klaus Granitzki, Baldur Junker, Ulrich Lagally, Ernst-Rüdiger Look, Ulrike Mattig, Ina Pustal, Heinz-Gerd Röhling, Matthias Thomae, Volker Wrede), 2003, Richtlinien zur Ausweisung als Nationaler GeoPark. In: Quade, H. (Hrsg.): Geoforum 2003. Geotope-Geoparks-Geotourismus. Schriften- reihe der Deutschen Geologischen Gesellschaft, Heft 35: 37-41; Hannover.

Mattig, U., Look, E.-R. \& Röhling, H.-G. (für die Koordinierungsgruppe "Geoparks" des Bund-Länderausschusses Bodenforschung: Dieter Göllnitz, Kurt Goth, Klaus Granitzki, Baldur Junker, Ulrich Lagally, ErnstRüdiger Look, Ulrike Mattig, Ina Pustal, Heinz-Gerd Röhling, Matthias Thomae, Volker Wrede), 2004, Richtlinien zur Ausweisung als Nationaler GeoPark. National GeoParks in Germany - Guidelines. Schriftenreihe der Deutschen Geologischen Gesellschaft, Heft 30, 34 S.; Hannover.

Quade, H., 2003, Geoforum 2003. Geotope-Geoparks-Geotourismus. Schriftenreihe der Deutschen Geologischen Gesellschaft, Heft 25, 120 S., 96 Abb., 4 Tab.; Hannover.

Quade, H., 2003, Nationaler Geotop- fachliche Bewertung und Ausweisung durch Prädikat. In: Quade, H. (Hrsg.): Geoforum 2003. Geotope-Geoparks-Geotourismus. Schriftenreihe der Deutschen Geologischen Gesellschaft, Heft 25: 31-36; Hannover.

Röhling, H.-G. \& Schmidt-Thomé, M., 2003, Geologické dě dictvy v Německu - geotopy a geoparky. [Geological Heritage in Germany: Geotopes and National GeoParks] - Ochrana Prírody, 59, č. 7: 208-212, Praha.

Röhling, H.-G. \& Schmidt-Thomé, M., 2004, Le patrimoine géologique en Allemagne: géotopes et géoparcs - Geologues 140: 28-33, Paris.

Dr. Heinz-Gerd Röhling received his professional education in Geology at the Universities of Giessen and Heidelberg. In 1984, he joined the Federal Institute of Geosciences and Natural Resources (BGR) at Hannover. Since 2001, he has been working as geologist in mapping, mineral exploration and research projects at the State Geological Survey of Lower Saxony, Hannover, where he is also responsible for geosites, geoparks and geotourism. He is member of the German Expert Group on National GeoParks of the GeoUnion Alfred-Wegener Foundation and is treasurer of the German Geological Society / German Society of Geosciences (DGG).

Dr. Michael Schmidt-Thomé is Head of the Division "Natural Resources, International Cooperation" of the Federal Institute of Geosciences and Natural Resources (BGR), Hannover, Germany. He received his professional education in geology at the Universities of Munich and Würzburg. In 1968, he joined the $B G R$ and gathered international experience as project manager in Technical Cooperation projects over 10 years. His scientific work concentrated mainly on the evolution of the Gondwana continent, particularly Antarctica. From 1989 to 1996, he was Treasurer of the International Union of Geological Sciences. Besides his responsibilities in BGR he is also Chairman of the German National GeoPark Expert Group.
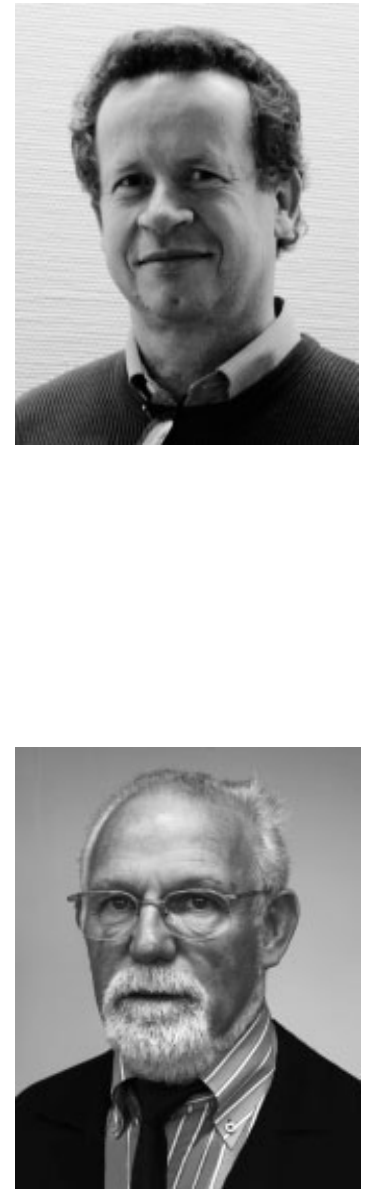